\title{
FISCAL FEDERALISM: US HISTORY FOR ARCHITECTS OF EUROPE'S FISCAL UNION
}

by

C. Randall Henning and Martin Kessler

BRUEGEL ESSAY AND LECTURE SERIES 


\section{FISCAL FEDERALISM: \\ US HISTORY FOR \\ ARCHITECTS OF \\ EUROPE'S FISCAL UNION \\ by \\ C. Randall Henning and Martin Kessler}


BRUEGEL ESSAY AND LECTURE SERIES

Fiscal federalism: US history for architects of Europe's fiscal union

C. Randall Henning and Martin Kessler

(c) Bruegel 2012. All rights reserved. Short sections of text, not to exceed two paragraphs, may be quoted in the original language without explicit permission provided that the source is acknowledged. The Bruegel Essay and Lecture Series is published under the editorial responsibility of Jean Pisani-Ferry, Director of Bruegel. Opinions expressed in this publication are those of the author alone.

\section{Bruegel}

33 , rue de la Charité, Box 4

1210 Brussels, Belgium

www.bruegel.org

ISBN: 978-9-078910-24-4 


\section{FOREWORD}

Ever since the blueprints for monetary union in Europe were first drawn up, the United States, considered as a collection of individual states or regions, has served as a benchmark for assessing its feasibility and evaluating alternative policy options. Starting with Robert Mundell's seminal 1961 article on optimal currency areas, countless papers have explored the inner workings of US labour, product and capital markets, and of its public finances, in the hope of learning lessons for Europe.

It could be argued that this US inspiration is mistaken. After all, it is not the only economic and monetary federation in the world. Other federations work on different principles - especially when it comes to public finances - and there is no guarantee that US arrangements are optimal - especially, again, regarding public finances. But we know the US better and we think we understand it better, so success or failure relative to the US test carries much more weight than with the Australian, Canadian, Indian or Swiss tests. For better or worse, the US remains our ultimate policy laboratory.

This essay on US fiscal federalism by Randall Henning and Martin Kessler builds on the established tradition. But unlike many papers that take current US features as a given, they tell us what present arrangements governing responsibility over public debt gradually emerged from, and why. By bringing in the historical dimension and the trial-and-error process that took place over more than two centuries, they help us understand the logic behind alternative arrangements and why the current one has in the end prevailed. 
Their careful historical account yields several important lessons. It first recalls that the US system as we know it, with its combination of a large federal budget responsible for the bulk of public debt and limited thrifty state budgets subject to balanced budget rules, emerged gradually from a sequence of events; in fact the initial set-up, as designed and enforced by Alexander Hamilton, was almost exactly the opposite. Second, it makes clear that beyond economic principles, attitudes towards what was in the aftermath of independence called the 'assumption' of state debt were shaped by broader political considerations - not least the aim of building a genuine federal government. Third, it explains how after the US was firmly established as a federation, changing political conditions led to a reversal of the federal government's stance and to the enforcement of a 'no bail-out' principle. An intriguing feature of US history is therefore that the competences and features of federal government grew out of its assumption of state debt, and that the centre imposed a de-facto no bail-out regime only after having assumed essential powers.

Another interesting observation by Henning and Kessler is that balanced budget rules were adopted spontaneously by states in response to financial stress and defaults, rather than as a disciplinary device mandated by the centre. Thus, there is still significant variability between states regarding the modus operandi and strictness of budget rules. The question remains if what matters is the strictness of the rule, or deeper political preferences at state level, of which the rule is only an expression.

Finally, as Henning and Kessler emphasise, a no less important lesson for Europe is that policy principles and institutions should be looked at as a system rather than in isolation. As the authors point out, it may seem obvious to recall that states in the US can abide by strict budget balance rules to the extent the federal government is responsible for stabilisation and the bail-out of insolvent banks, but this simple lesson is sometimes overlooked in European discussions. 


\section{FISCAL FEDERALISM: \\ US HISTORY FOR ARCHITECTS OF EUROPE'S FISCAL UNION}

\section{INTRODUCTION ${ }^{1}$}

However the euro area navigates its immediate financial crisis, fundamental reform of fiscal governance - institutions, rules, and procedures - will remain a central part of its long-term agenda. The relationship between the monetary union and its member states is at the heart of the debate. The European Council in December 2011 decided on a 'fiscal compact' for the euro area that includes the adoption of a new rule restricting deficits by member states in their constitutions or framework laws - 'debt brakes'. This measure complements an array of other provisions to prevent the emergence of large fiscal deficits and strengthen the sanctions for rule violations. Debate continues over whether the euro area must create a deeper fiscal union, including the introduction of joint and several responsibility for bonds.

These debates about Europe's future often reference the historical experience of the United States. Some salient features of US fiscal federalism that are frequently addressed in the literature on European monetary integration include the (i) transfers that take place between the federal government and the states, (ii) absence of federal bailouts of the states, and (iii) limitations on the deficits of the individual states and their correspondingly low debt.

This essay briefly reviews American fiscal history in light of questions confronting the future of fiscal union in the euro area. We draw lessons 
for the dilemmas that Europe faces and point readers to particularly illuminating episodes and references in the literature on the United States. The fact that states encountered major debt crises and defaulted, yet the union managed to overcome them intact, points to relevant lessons for European policymakers in the current turmoil. There is a deep and varied literature and we have not exhausted it; but we believe that readers will be well rewarded by referring to the contributions listed here. Focusing on the problem of how to grapple with dysfunctional members of a union, and placing the financial challenge in political and historical context, this essay is a hybrid of analytical interpretation and literature review. The euro area will not want to replicate US institutions, but will want to bear in mind the lessons from US successes and mistakes when redesigning its own institutions. We consider first the key phases in US fiscal history, and then examine issues and lessons relating to balanced budget rules that have been adopted by the states.

\section{US FISCAL HISTORY IN A NUTSHELL}

The fiscal history of the US federal government and its relationship to state and local governments can be assessed in five phases or episodes: (1) Alexander Hamilton's reforms immediately after the establishment of the new federal government under the US Constitution in 1789; (2) state defaults during the 1840s; (3) a series of defaults at state and local level after the Civil War; (4) the Great Depression of the 1930s; and (5) scattered municipal defaults between 1970-2010. We consider each in turn, devoting somewhat disproportionate attention to the early, formative period.

\section{Hamilton's plan}

The first Secretary of the Treasury, Alexander Hamilton, has been credited with creating a modern financial system for the new United States 2 . The magnitude of his achievements becomes clear when the prior condition of the US economy is considered. Before 1790, the United States 
was effectively bankrupt, in default on most of its debt incurred during the Revolutionary War, and had no banking system, regularly functioning securities markets or national currency ${ }^{3}$. The federal government was reliant on the thirteen states to collect and share tax revenue, and was unable to pay war veterans or to service, let alone redeem, debts. Under the Articles of Confederation, the federal government had no executive branch, judicial branch or tax authority. As an 'institutional equilibrium', the United States were decidedly unstable and the financial predicament largely drove the constitutional reform of 1787 in Philadelphia.

After George Washington was inaugurated as President in April 1789, and Hamilton was confirmed, the new treasury secretary began to propose a series of institutional innovations on which he had been cogitating for at least a decade. Based on the secretary's study of British and Dutch financial institutions, these proposals included the establishment of the Bank of the United States, the mint, securities markets, and, most interestingly for our purposes, the assumption of state debts by the federal government. These were to be complementary, mutually reinforcing elements of the new American financial architecture. He delivered the first of his blueprints in the form of the Report on Public Credit to Congress in January 1790 (Chernow, 2004, pp297-306; Hamilton, vol. 6, Report on Public Credit).

The debt assumption plan involved the transfer of state debt to the federal government in the amount of $\$ 25$ million. Added to existing federal debt owed to foreign governments (France) and domestic investors, amounting to $\$ 11.7$ million and $\$ 42.1$ million respectively, federal debt would then amount to $\$ 79.1$ million (Sylla, 2011) - a very large sum compared to nominal GDP in 1790 , which is estimated at $\$ 187$ million. In at least three prolonged debates over the course of 1790 and 1791, opponents in Congress levelled several arguments against the various elements of the plan. They objected that it (1) would reward speculators who had purchased debt from (distressed) original investors; (2) was unfair, as some states (such as Massachusetts and South Carolina) would be relieved of greater bur- 
dens than others (such as Virginia and North Carolina); and (3) would empower the federal executive at the expense of Congress and the states.

Thomas Jefferson, who reluctantly served as Secretary of State in Washington's first administration, levelled particular criticism at the Bank of the United States, which Hamilton proposed should help manage the assumed federal debt, hold federal tax receipts and provide intermediation. Only three banks existed in 1789 and state governments served as financial intermediaries (Savage, 1988, p99). The Bank of the United States was to be capitalised at $\$ 10$ million - several times larger than the combined capital of existing banks - with $\$ 8$ million held by the private sector and $\$ 2$ million held by the US government. The federal government's share was to be paid in Treasury securities, as would three-quarters of the private share, thus harnessing the assumption plan to the development of the new financial system. Jefferson argued strenuously that the bank, not specifically provided for at the Philadelphia convention, was unconstitutional.

Hamilton addressed these objections systematically, arguing against 'discrimination' between the original and present holders of debt on the grounds not only of fairness but also that it was essential for an efficient, unified securities market. He justified 'assumption' on the grounds that state debt was issued for a common purpose: to prosecute the War and secure independence. He defended the constitutionality of his proposals by arguing that, even though the Constitution did not mention the establishment of a new bank, the authority to do so was implied by granting the executive the responsibility for the financial affairs of the federal government - the 'implied powers doctrine', which became a permanent feature of US constitutional law (Chernow, 2004, pp344-61).

More fundamentally, Hamilton saw his plan as not simply a way to secure credit for the federal government, or even to establish a national financial system, but as a grand political project. He envisaged the plan as (1) aligning the issuance of debt with the tax base, securing 
from the individual states the federal government's claim to the tax base reserved to it under the Constitution (tariffs), (2) securing for the federal government the allegiance of the holders of federal debt and the financial system revolving around it, and (3) generally binding the states to the union (Hamilton, Report on Public Credit).

As part of the plan - and this point is sometimes lost in reviews of this period - Hamilton restructured the debt. The restructuring applied to both prior federal debt and the newly assumed state debt. The secretary adopted a menu approach to debt exchange of (a) a bond paying 6 percent, equal to the previous rate, (b) a bond paying 3 percent, and (c) one paying 6 percent but on which interest was deferred for ten years. He sweetened the offer by providing call protection (the Treasury could not withdraw bonds when the interest rate fell) and a sinking fund to assure repayment (Sylla and Wilson, 1999; Ratchford, 1941, pp52-72; McGrane, 1935). Investors were offered a swap of old debt for a combined package of the three new bonds, on a voluntary basis. The new bonds were perpetual, without a redemption date, on the model of British consols. By the time Hamilton left office in early 1795, 98 percent of domestic (federal and state) debt had been exchanged on these terms. Foreign debt, mainly to France, was repaid in full, with accrued interest, with the proceeds of a new loan from Dutch bankers (Sylla, 2011, pp11-13].

The implementation of the assumption plan quickly became embroiled in distributional conflict among the states. The federal government assumed $\$ 18.3$ million in state debt in 1790 and charged the states accordingly through accounts that were to be settled in order to equalise the per capita costs of financing the Revolutionary War. The creditor states ended up being owed $\$ 3.5$ million by the debtor states and were issued this amount in new federal bonds plus another $\$ 0.5$ million to cover interest arrears, raising total state debt assumed to $\$ 22.5$ million. The debtor states were forgiven the corresponding balances that they owed ${ }^{4}$. Albert Gallatin, who served as treasury secretary in the Jefferson and Madison administrations, argued that Hamilton assumed $\$ 10.9$ million more of state debt than would have 
been necessary had the settlement of accounts been concluded before assumption. Hamilton defended the sequencing as important for avoiding a conflict between the state and federal levels over the tax base, which, with the exception of import tariffs, was subject to the concurrent jurisdiction of the two levels ${ }^{5}$.

The contemporary debate over monetary union in Europe appears polite compared to the ferocity with which Hamilton's plan was debated in Congress. The assumption plan was rejected once by Congress and then stitched into a famous compromise relocating the seat of government from New York to the District of Columbia. But the debate effectively reopened the fragile constitutional compromise of 1787 over the balance to be struck between the states and the union, and between Congress and the executive ${ }^{6}$. The politics around these issues were so vituperative in spring 1790 that, in Chernow's (2004, p326) assessment, it would not have been far-fetched to think that the union could break up?. As it was, the episode crystallised opposing forces in American politics and forced the irreconcilable split between the 'Federalists', led by Hamilton, and the 'Democratic Republicans', led by Jefferson and James Madison, that was to define American politics for decades (Chernow, 2004, pp320-331). The Bank of the United States became the primary battlefield for this ongoing factional conflict ${ }^{8}$.

\section{Establishing the 'no-bailout' norm in the 1840s}

Although a critical part of the US financial system, the debt assumption of 1790 set a precedent that endured for several decades. The federal government assumed the debt of states again after the War of 1812 and then for the District of Columbia in 1836. During this period, the possibility of a federal bailout of states was a reasonable expectation; moral hazard was substantially present. This pattern was broken in the 1840s, when eight states plus Florida, then a territory, defaulted.

Hamilton had wanted to make the federal government the sole creditor of the states with the assumption plan (Rodden, 2006, p57), but was unsuccessful. With the exception of the War of 1812 , states issued 
relatively little debt during the early nineteenth century and levied correspondingly few taxes. Land sales, bank charters and various investments were the main sources of state revenue, and the role of state government was quite limited. Westward expansion during the 1820 s and 1830s, however, gave rise to demands for infrastructure, such as canals and turnpikes - which could only be financed through borrowing. This borrowing was done on the theory that debt would be serviced and repaid by tolls and other project revenue, without raising taxes, dubbed 'taxless finance' (Wallis, 2005). The Erie Canal was one of the first and most financially successful of these projects. With the financial panic of 1837 and recession of 1839-43, however, much of the debt incurred became unserviceable.

The indebted states petitioned Congress to assume their debts, citing the multiple precedents. British and Dutch creditors, who held 70 percent of the debt on which states later defaulted, pressed the federal government to cover the obligations of the states. They argued that the federal government's guarantee, while not explicit, had been implied. Even the prices of bonds of financially sound states fell, and the federal government was cut off from European financiers in 1842. In that year, Lord Ashburton, the main British negotiator for Barings, wrote that the United States was an "ungovernable and unmanageable anarchy" (Roberts, 2010). John Quincy Adams evidently believed that another war with Britain was likely if state debts were not assumed by the federal government ${ }^{9}$.

However, on this occasion Congress rejected the assumption petition and was able to do so for several reasons. First, debt had been issued primarily to finance locally beneficial projects, rather than national public goods. Second, domestically held bonds were not a large part of the US banking portfolio, and default had limited contagion effects, at least through this particular channel. Third, the financially sound states were more numerous than the deeply indebted ones. And, finally, the US economy had matured to the point where it was less dependent on foreign capital. Foreign loans were crucial to Hamilton's plan in 1790 , but they were a minority contribution when investments eventually 
resumed in the 1850s (McGrane, 1935, pp21-40; Savage, 1988, pp105-118; Wibbels, 2003; Wallis, 2005).

Eventually, most states repaid all or most of their debt as a condition for returning to the markets. The State of Maryland provides a good example. It had financed the construction of the Chesapeake and Ohio Canal, the Baltimore and Ohio Railroad, which competed with the canal project, and a number of other railroads. When state officials were unable to service the debt with revenues from these projects, they had no system of direct taxation on which to fall back, and the value of real property declined quickly. The state suspended payments on bonds between 1841 and 1847, but resumed payments thereafter, including accrued interest, and accessed the British market through Barings again in 1849. The state paid off its pre-crisis debt by 1851 (McGrane, 1935, pp82-101]. However, Maryland and the states that had defaulted returned to markets at a premium, whereas the others were able to borrow at normal rates relatively soon after the crisis (English, 1996).

The rejection of debt assumption established a 'no bailout' norm on the part of the federal government. The norm is neither a 'clause' in the US Constitution nor a provision of federal law. Nevertheless, whereas no bailout request had been denied by the federal government prior to 1840 (Ratchford, 1941), no such request has been granted since, with one special exception discussed below. The fiscal sovereignty of states, the other side of the no-bailout coin, was thereby established.

During the 1840 s and 1850 s, states adopted balanced budget amendments to their constitutions or other provisions in state law requiring balanced budgets. This was true even of financially sound states that had not defaulted. The adoption of balanced budget rules continued over the course of subsequent decades, so that eventually threefourths of the states had adopted such restrictions. Because this is a direct analogue to the adoption of constitutional 'debt brakes' in the euro area, it is important to understand the political economy of the adoption of these provisions of the states in the nineteenth century. We devote a section to this topic below. Suffice to say at this point, 
however, that several states did not adopt such amendments and in 1860 , on the eve of the Civil War, collective state indebtedness stood at $\$ 247.4$ million, $\$ 67.5$ million greater than in 1841 . This sum was four times the size of the federal debt (Savage, 1988, p118).

\section{$\underline{\text { Reconstruction defaults }}$}

After the Civil War, the process of reintegrating the Southern states into the Union and reviving their economies - 'Reconstruction' - witnessed an extraordinary degree of corruption and political dysfunctionality ${ }^{10}$. "As soon as the military authorities were removed," writes Ratchford (1941, p170), "the Reconstruction governments rushed to plunder public treasuries. Since those treasuries were usually empty and since the possibilities of taxation were severely limited, the only alternative was to despoil the public credit". By the end of Reconstruction in 1874, the total debt of the eleven Southern states had risen to $\$ 247.6$ million from $\$ 111.4$ million in 1865 . Most of it took the form of direct state bonds or guarantees of railroad company bonds. Ratchford (1941, p180) estimates that about $\$ 12$ million of these bonds was sold abroad. Much of this new debt was regarded as odious by Southern electorates, imposed by "corrupt and hostile governments supported by outside military force"11. Eight states thus repudiated part of their debt or reduced it by other not-so-voluntary means by $\$ 116.3$ million over the next sixteen years.

Although the no-bailout position of the federal government vis à vis the states had been established prior to the Civil War, the position of the states themselves vis à vis their counties and cities remained to be tested. During Reconstruction, many local governments also accumulated debt that they were unable to service during the 1870 s. Almost all of this debt was held abroad or by out-of-state residents - a pattern facilitated of course by integrated capital markets - and the taxes necessary to repay would have come from upper-income households. States successfully fended off petitions for bailouts - none were provided - and all states re-wrote their constitutions to prohibit them (Inman, 2003, p58 and p65), and several strengthened limits on 
issuance of their own debt ${ }^{12}$. Remarkably, Inman (2003) records only one instance of state bailout of a municipality (Camden, New Jersey) in the history of the United States ${ }^{13}$.

\section{Great Depression and fiscal shift}

The 1930s saw another wave of defaults by local governments and the last default to be recorded by a state. Between 1920 and 1930 capital investment by local governments doubled, financed by general obligation bonds backed by property tax. Owing to the collapse in the tax base with the Depression, by December 1935 more than 3,200 local governments had defaulted on $\$ 2.4$ billion of these debts. This debt was owed to domestic rather than foreign investors, yet neither state nor federal bailouts were provided. Instead, massive fiscal shifting took place as states and the federal government adopted new programmes, taking over some functions from local government, and provided direct assistance as local government cut spending (Inman, 2003, p59). There was a complete reversal in the relative shares of total government spending of the three levels over the course of the Depression. Whereas in 1932 local governments spent 50 percent, states 20 percent and the federal government 30 percent of the total, by 1940 local governments spent 30 percent, states 24 percent, and the federal government 46 percent (Wallis, 1984). The period thus marks the ascendance of the federal government relative to the states and, notwithstanding President Franklin D. Roosevelt's instinctive fiscal conservatism, the introduction of countercyclical demand management at the federal level. Most of the defaulted debt and interest was repaid in full by 1940 (Inman, 2003, p66). The last state default occurred in 1933 when Arkansas suspended payments on its highway bonds. By 1943, the majority of defaulting issues were refinanced and the state returned to good standing in debt markets (Ang and Longstaff, 2011).

\section{0-2010: scattered municipal bankruptcies}

Over the last several decades, until the 2008-09 crisis, the United States did not see a wave of bankruptcies but rather a series of 
relatively isolated municipal problems. Between 1970-2009, 54 municipal bond issuers defaulted, while between 1988-2009 about 170 jurisdictions declared bankruptcy (Kasparek, 2011, p16). The case of New York City in 1975 is remembered by the headline in the New York Daily News, 'Ford to New York: Drop Dead'. The city's rescue was primarily organised by the Governor of New York through the Municipal Assistance Corporation (MAC). When Philadelphia encountered problems in 1990, the response was organised by the state of Pennsylvania. The cities of Bridgeport and Miami and Orange County defaulted. However, the states did not provide funds to repay bondholders in these cases. The single exception to this rule is the state of New Jersey, which bailed out the city of Camden (Inman, 2003, p60). The bankruptcy filing of Jefferson County, Alabama, in November 2011, is the most recent; it follows the bankruptcy filing by Harrisburg, Pennsylvania, and a couple of other cities ${ }^{14}$.

The single exception to the federal government's no-bailout position is the case of the District of Columbia in the 1990s, an exception that proves the rule. In this case, Congress did indeed take control of the District's finances, injected funds, and managed the budget for four years though the District of Columbia Financial Control Board, created in 1995, which left the city in surplus after four years. This was possible because of a special clause in the Constitution giving Congress authority over the administration of the District - authority that does not extend to the 'sovereign' states ${ }^{15}$.

In the present crisis, the finances of the states of California and Illinois have captured attention. Both states have large populations and economies -13 percent and 4.5 percent of national GDP respectively - and have large budget deficits and dysfunctional politics. Both states also have balanced budget amendments in their state constitutions, illustrating the leaky character of these provisions ${ }^{16}$. The size of these states and the impact of a default by one of them on US financial markets have generated speculation about the possibility of a federal bailout in extremis. While this might be a possibility in the abstract, the absence of a modern precedent places a high institutional bar on such 
action. The expectation of such a bailout is hardly detectable in the domestic political wrangling within both states; their political parties seem resigned to resolving these issues independently.

\section{BALANCED BUDGET RULES}

In light of the provisions being adopted in Europe, three aspects of the balanced budget rules of the states deserve elaboration: (1) the politics of their propagation; (2) the exact nature of the requirements and their variation among the states; and (3) their effectiveness in limiting deficits.

\section{Emergence}

The adoption of balanced budget rules among most of the states during the nineteenth century raises a number of interesting questions. What drove the adoption across disparate states? Did capital markets insist on them by discriminating between states with provisions and those without? What role did voters and elections play? Did the federal government promote these rules? The published work casts some light on these questions; but many questions remain to be addressed by future research.

The first wave of adoptions among nineteen states between 1842-57 is closely linked to the financial panic of 1837 and subsequent economic depression. According to Wallis (2005) and Wallis and Weingast (2008), the emergence of balanced budget rules should be understood as the demand of voters for more transparent and realistic financing rules. All of the states that defaulted in the 1840s except Florida, Mississippi and Arkansas, wrote some kind of deficit restriction into their constitution immediately afterward. The point was not so much to forbid deficits altogether, but to avoid 'taxless finance' and other forms of infrastructure financing which were either not sustainable or easily led to corruption ${ }^{1 ?}$. Quite often, state governments were forced to obtain public approval by referendum to issue debt for a project and 
simultaneously increase taxes in order to service it. New states admitted to the Union after the Civil War generally included debt limits in their constitutions (Ratchford, 1941, p122, whose explanation is consistent with Wallis and Weingast].

The federal government was passive during the adoption of these provisions by the states. The federal government certainly did not mandate the adoption of these provisions and it does not appear that it was promoting them either. Nor does it appear that states pressed for conformity on the part of their neighbours, or even, by these accounts, that states were competing against one another for access to lowercost financing by adopting them. Existing treatments suggest that states were acting autonomously, though the financial challenges were common, and the political pressures for adoption were internal. By contrast, the current adoption of 'debt brakes' in the euro area is driven more by the most dominant member states and the euro-area institutions. But internal support is almost surely necessary for the meaningful implementation and perpetuation of these rules. The episode of the 1840 s also underscores the importance of crisis as a driver of institutional change, which is reflected in the contemporary European experience.

\section{$\underline{\text { Rule characteristics }}^{18}$}

Because each state adopted its own balanced budget rule (Vermont is the only state without such a rule in some form], there is a large variation in the way these rules function. According to the National Association of State Budget Officers (NASBO), which surveyed State Budget Controllers, 44 states have a constitutional or statutory rule that requires the governor to submit a balanced budget, 41 require the legislature to pass a balanced budget, while 37 demand that the governor signs a balanced budget. Finally, 43 states simply forbid carrying over a deficit to the next budget plan (annually or biannually). Note however that different readings of state laws or jurisprudence have led some academics or institutions to rank the restrictiveness of these provisions differently. 
Balanced budget rules usually apply only to the state's general fund, which receives most tax collections and from which most expenditures are made. Grants and reimbursements from the federal government make up most of states' non-general fund: those funds are balanced de facto because federal grants are earmarked for specific projects, and the money spent matches the money received. Moreover, most states have separate operating and capital budgets; bond finance for capital projects does not fall within most balanced budget rules (NCSL, 2010). Therefore most balanced budget rules are 'golden ${ }^{19}$. Note, however, that unfunded liabilities are often excluded from state debt calculations, and rules sometimes allow the diversion of revenues from pension funds to the general fund, aggravating the underfunding of obligations in the long run.

Finally, it must be noted that, while we have focused on balanced budget rules, rules that apply specifically to expenditure or taxes also have a substantial impact on the budget behaviour of states. Some states, such as California, require a supermajority (or qualified majori$t y$ ) in the legislature to raise taxes. Poterba and Rueben (2001) show that such limitations on tax increases tend to raise state bond yields. Conversely, constraints on the spending side seem to facilitate lower yields. 'Rainy day funds', another common fiscal instrument, allow states to save and smooth the fiscal path, by saving at the crest of the business cycle.

\section{Effectiveness}

Balanced budget rules have not prevented states from getting into fiscal trouble - witness the recent experience of California and Illinois. On the other hand, the overall debt of states has been reasonably well contained. In 2009, California's was less than 8 percent of state GDP, New York 11.2 percent, and New Jersey 12.1 percent (see Table 1). Political scientists and economists have tried to untangle the effects of these provisions from factors such as party control of state government, political culture and capital markets (see Poterba 1996; Bayoumi, Goldstein and Woglom, 1995, on market discipline; Rose, 
Table 1: Debt and deficits of 'problem states', 2009-11

\begin{tabular}{l|ccc|c|c}
\hline & \multicolumn{2}{|c|}{$\begin{array}{c}\text { Deficit as a \% of general } \\
\text { fund }\end{array}$} & $\begin{array}{c}\text { State debt as } \\
\text { \% of GDP }\end{array}$ & $\begin{array}{c}\text { State and local } \\
\text { outstanding debt } \\
\text { as \% of GDP }\end{array}$ \\
\hline Arizona & 2009 & 2010 & 2011 & 2009 & 2009 \\
California & $36.8 \%$ & $65.0 \%$ & $39.0 \%$ & $4.9 \%$ & $19.4 \%$ \\
Nevada & $19.7 \%$ & $52.8 \%$ & $20.7 \%$ & $7.3 \%$ & $20.2 \%$ \\
Illinois & $15.1 \%$ & $46.8 \%$ & $54.5 \%$ & $3.6 \%$ & $20.7 \%$ \\
\hline New Jersey & $18.8 \%$ & $40.0 \%$ & $38.2 \%$ & $12.1 \%$ & $19.6 \%$ \\
\hline New York & $13.2 \%$ & $38.8 \%$ & $15.9 \%$ & $11.2 \%$ & $26.8 \%$ \\
\hline
\end{tabular}

Source: McNichol, Oliff and Johnson (2011); data for 2011 is estimated from state sources; Bureau of Economic Analysis for debt data; Census Bureau for state GDP up to 2009. Note: The states selected had the largest deficits in 2010 as a percentage of their general fund.

\section{BOX 1: TWO EXAMPLES OF BALANCED BUDGET RULES}

\section{California:}

In 2004, by referendum, California passed Proposition 58, also called the 'Balanced Budget Act', which reinforced the previous balanced budget rule by constitutional amendment. The specific provision, now included in the constitution as article IV, section $12(\mathrm{~g})$ states:

"For the 2004-05 fiscal year, or any subsequent fiscal year, the Legislature may not send to the Governor for consideration, nor may the Governor sign into law, a budget bill that would appropriate from the General Fund, for that fiscal year, a total amount that, when combined with all appropriations from the General Fund for that fiscal year made as of the date of the budget bill's passage, and the amount of any General Fund moneys transferred to the Budget Stabilization Account for that fiscal year pursuant to Section 20 of Article XVI, exceeds General Fund revenues for that fiscal year estimated as of the date of the budget bill's passage. That estimate of General Fund revenues shall be set forth in the budget bill passed by 


\section{the Legislature".}

The Act also allows the Governor to proclaim a fiscal emergency in specified circumstances, and to submit proposed legislation to address the fiscal emergency; requires the Legislature to stop other action and act on legislation proposed to address the emergency; establishes a budget reserve; provides that the California Economic Recovery Bond Act is for a single object or work; and prohibits any future deficit bonds.

\section{Illinois:}

Article VIII, Section 2 of the Constitution of Illinois reads:

a) The Governor shall prepare and submit to the General Assembly, at a time prescribed by law, a State budget for the ensuing fiscal year. The budget shall set forth the estimated balance of funds available for appropriation at the beginning of the fiscal year, the estimated receipts, and a plan for expenditures and obligations during the fiscal year of every department, authority, public corporation and quasi-public corporation of the State, every State college and university, and every other public agency created by the State, but not of units of local government or school districts. The budget shall also set forth the indebtedness and contingent liabilities of the State and such other information as may be required by law. Proposed expenditures shall not exceed funds estimated to be available for the fiscal year as shown in the budget.

b) The General Assembly by law shall make appropriations for all expenditures of public funds by the State. Appropriations for a fiscal year shall not exceed funds estimated by the General Assembly to be available during that year. 
2010 , for a general survey). Our bottom line from a review of this literature is that balanced budget rules probably do have salutary independent effects on debt accumulation but that interaction with the political environment and markets is critically important.

First, there is a great deal of variation in the strictness of rules among states and more stringent conditions lead to less borrowing. Bohn and Inman (1996) estimate that a requirement that the budget be balanced at the end of the year reduces the probability of a deficit from 26 percent to 11 percent. The rule has stronger effects when it is inscribed in the constitution and exceptions require a qualified majority in the legislature. Requiring preparation of a balanced budget is easily circumvented by optimistic economic projections, whereas prohibitions on carrying over a deficit from one year to the next are effective (see, Hou and Smith, 2009, who distinguish between 'political' and 'technical' provisions, and Mahdavi and Westerlund, 2011). Enforcement also varies among states, with Virginia, for example, lacking a binding mechanism (NCSL, 2010). In the 26 states in which Supreme Court judges are elected, rather than nominated by the governor and confirmed by the legislature, the rules are enforced more strictly and deficits thereby limited (Bohn and Inman, 1996).

Second, states with stricter rules are better perceived by the market. Poterba and Rueben (1999) show that weak provisions cost 10 to 15 basis points, when compared to similar states with stricter anti-deficit rules. In a subsequent paper (Poterba and Rueben, 2001), they show that unexpected deficits lead to higher yields for states with weak rules than states with strong rules.

Third, several studies have found the effectiveness of balanced budget rules to be contingent on the politics within the state, such as unified party control of both houses of the legislature (Alt and Lowry, 1994) and unified control of the governorship and legislature (Poterba, 1994, as cited in Briffault, 1996). Inman (1998) admits that scholarship cannot rule out the possibility that balanced budget rules are adopted by states that are fundamentally fiscally conservative and thus have 
little independent impact (the endogeneity problem). After reviewing the literature of the mid-1990s, Briffault (1996, p60) concludes: "It seems likely that the real importance of a constitutional balanced budget requirement is that it signals the high value that a state's political culture sets on a balanced budget. A state with such a constitution may be more likely to balance its budget, but that is less attributable to the independent force of the legal requirement than to the political values and tradition that put it in the constitution in the first place". The likely effectiveness of balanced budget rules that are adopted by euroarea member states in the midst of the present crisis should be assessed in this light.

\section{MACROECONOMIC STABILISATION}

Because state and local budgets are about 40 percent of total government spending in the United States, fiscal policy is effectively shared by the levels within the federal system. This is often not given due recognition in the discourse about macroeconomic stabilisation, in which the role of the federal government is sometimes an exclusive focus. Balanced budget provisions of the states do not provide for cyclical adjustment of the calculated deficit. These provisions, to the extent that they are effective, require raising taxes and/or cutting spending when revenue falls during recessions. The size of this effect can offset a substantial portion of the countercyclical movement of the federal budget position. Krugman (2008), for example, refers to the states as the 'fifty little Herbert Hoovers', pursuing fiscal contraction when Keynesian measures were in order as the United States was sliding into the 'Great Recession'.

The conventional wisdom has been that the budget positions of state and local governments move procyclically in the United States. Poterba (1994) found strong evidence for this, and that states with stricter balanced budget rules cut spending more than those with looser rules during recessions. The strength of this finding appears to vary over time and over the business cycle, with some studies concluding that 
state and local budgets overall are neutral or even weakly countercyclical (Sorensen, Wu and Yosha, 2001; Hines, 2010). Sorensen and Yosha (2001) report that state budget positions are countercyclical at the top of the business cycle but procyclical in recessions. During the Great Recession and slow recovery, most studies find that state and local budgets have acted procyclically (Aizenman and Pasricha, 2010; Follette and Lutz, 2010; and Kasparek, 2011), while some find neutrality (Hines, 2010). These studies agree, however, that in the aggregate $^{20}$, state and local budgets do not help to stabilise the macroeconomy during recessions; that role is played by the federal government in the United States ${ }^{21}$.

Fiscal transfers from the federal government directly into state budgets, to help them fulfil federal mandates and otherwise alleviate budget pressure, ameliorate the procyclical influence of the states during downturns ${ }^{22}$. The American Recovery and Reinvestment Act (ARRA) of 2009, for example, provided large amounts of support to the states. According to the Bureau of Economic Analysis (BEA), the level of total grants-in-aid to state and local governments in 2009 was $\$ 482$ billion, $\$ 70$ billion of which came from the stimulus package. Federal support then rose to $\$ 532$ billion in 2010 , of which $\$ 100$ billion was accounted for by ARRA . A large part of the support was directed through Medicaid to cover the shortfall of revenues at the state level. The rest was either spent in the education sector or earmarked for various investment projects (see Table 2). In 2010, according to the Congressional Budget Office ( $\mathrm{CBO}$ ), 75 percent of the grants to states contained in the stimulus package were used to finance state deficits rather than fund new projects. The high-profile protests in mid-Western states during summer 2011 responded to state expenditure reductions that in large measure were done in anticipation of the phasing out of federal stimulus.

In sum, the federal government (1) is the only level that provides significant stabilisation during recessions, while the states are likely to be procyclical, and (2) injects federal money into state programmes directly. Both roles render the balanced budget rules at the state level 


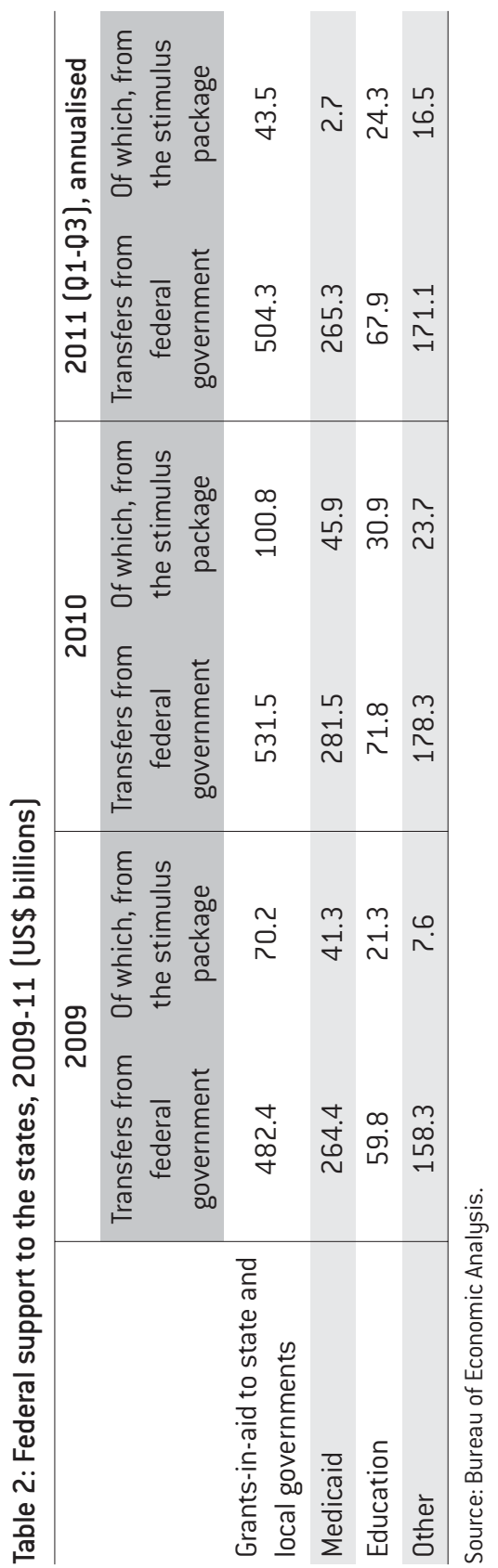


more sustainable than they would be in the absence of the federal government and its fiscal system.

\section{FINANCIAL MARKETS AND CONTAGION}

US banking and capital markets are another element of the context in which budget rules operate and in which the states relate to the federal government on fiscal matters. Consider first the capital markets and then the organisation of banking, its regulation and restructuring.

State and local government debt in the United States totalled $\$ 2.45$ trillion at the end of 2010, 16.7 percent of GDP. Of this amount, roughly 40 percent had been issued by states and 60 percent by local entities. This compared to federal debt held by the public of $\$ 9.36$ trillion, or 64.4 percent of GDP. Most of the state and local debt is longer than one year, with an average maturity of over 14 years, issued to finance capital expenditures; relatively little has been issued to finance current spending $^{23}$. Thus, only 16 percent of outstanding debt is general obligation bonds backed by the full faith and credit of the issuer; the vast majority is secured by the revenue stream of infrastructure and other investment projects. Balanced budget rules thus appear to have been effective in configuring the composition of state debt and the recourse of investors. Half of outstanding state debt is accounted for by seven states - California, New York, Massachusetts, Illinois, New Jersey, Pennsylvania, and Florida - with California and New York representing 12.9 and 11.7 percent respectively. Most of these bonds are sold within the US, the interest on them being exempt from federal income tax. These outstanding obligations comprise the municipal bond market in the US ${ }^{24}$.

Municipal bonds normally trade at a premium relative to US Treasury securities, owing to the federal tax exemption. From 2005-07, for example, the yield on ten-year municipal bonds was roughly one percent below ten-year Treasury bonds. That relationship was reversed briefly during the acute phase of the crisis at the end of 2008 and restored in 
spring 2009, with the spread evaporating at the end of 2010 and remaining quite narrow through 2011 . Shocks in state bond markets generally do not appear to have substantial consequences for the markets in Treasury securities and vice versa ${ }^{25}$.

Do the markets effectively discriminate among the bonds of different states? As of late 2011, Standard and Poor's rates thirteen states AAA, fourteen states $A A+$, seventeen states $A A$, four states $A A-$, one state (Illinois) A+ and one state (California) A- ${ }^{26}$. Between 2004 and 200?, when European sovereign bond spreads were nearly eliminated, the average spread between the Aaa and Bbb state bonds (using Moody's ranking) were in the range of 58 to 46 basis points. That spread rose to 207 basis points during the crisis in 2009 and declined somewhat in 2010. Credit default swap (CDS) markets emerged for the bonds of eleven states during the Great Recession. Yields on California bonds spiked to 4.55 percent in December 2008, when its CDS rate peaked over 500, and fluctuated in the neighbourhood of 3 percent thereafter. Ten-year CDS rates ranged from 288 for California and 284 for Illinois to about 65 for Texas, Virginia and Maryland in September 2011.

The operation of the US municipal market suggests comparisons to those of the European sovereign market. Markets seem to have been more discriminating among the US states than euro-area members during the quiescent mid-2000s, particularly given the relatively small differences in the debt load of the states compared to the differences in those of the euro-area members. Whether the markets' extreme differentiation of European sovereign bonds between 2010-11 is fully justified is beyond the scope of this paper, in comparison, the markets' moderate differentiation among US state bonds seems to be broadly proportionate to risk $^{2 ?}$.

How effectively do US institutional arrangements and market structures insulate one state from the fiscal mistakes of another, given that an individual state default might trigger systemic risk? One might expect that macroeconomic contagion should be much stronger in a tightly integrated federation such as the US than in a more loosely 
integrated one (Auerbach, 2011). However, spillovers in the US municipal market tend not to be of the 'contagious' type but of the 'flight-to-quality' type. When the large borrowers such as California, Georgia, Maryland and the City of New York experience problems, other issuers see their yields fall (Arezki, Candelon and Sy, 2011). Although contagious linkage is sometimes found, such as between California and New York bonds, studies using CDS data also generally find that insulation is strong (Ang and Longstaff, 2011).

State bond yields could move more independently than the level of macroeconomic integration would lead us to expect for several reasons. First, the existence of a deep and liquid market in US Treasury securities as a 'safe haven' might play a role that has not been sufficiently investigated. Second, US banks do not seem to transmit shocks to states as European banks do to European sovereigns, probably owing to differences in bond ownership and regulatory frameworks (Ang and Longstaff, 2011). Third, setting fiscal rules independently in each state and enforcing them internally might isolate deviant behaviour and protect others, whereas a rule set and enforced centrally (such as the excessive deficit provisions of the Maastricht Treaty and the Stability and Growth Pact) might quickly lose credibility when one sovereign breaches it.

Fundamental characteristics of the US financial system are germane to the operation of the municipal bond market and to the role of balanced budget rules. Banks are less important conduits for finance in the United States than they are in Europe. Only 8.6 percent of state bonds outstanding were owned by US commercial banks in 2010. Although state regulation of banks was the norm in earlier periods, US banking regulation is now far less geographically fragmented than in Europe. During the savings and loan banking crisis of the 1980s, which had a strong regional dimension, the federal government took primary responsibility for the restructuring. During the far larger rescue and restructuring of the banking system during 2008-10, the states played very little role. The risk pool is nationwide in the United States and the bank rescue did not impair the fiscal position or creditworthiness of the 
individual states. Although Europe has taken substantial steps toward a common regulatory framework, the contrast with the United States remains stark.

\section{CONCLUSION: RAMIFICATIONS FOR EUROPE}

We have reviewed US fiscal federalism, from Alexander Hamilton to the present, to provide insights for the architects of fiscal federalism in Europe. The US federal government has not bailed out state and local governments since the early nineteenth century and the no-bailout norm has been formed politically; there is no clause in the Constitution. States adopted balanced budget rules of varying strength during the nineteenth century and these rules seem to be consequential, sometimes as a constraint, sometimes as a signal to capital markets, for state fiscal policy.

Balanced budget rules among the states seem to parallel the effort adopted at the March 2011 European Council meeting and affirmed at the December 2011 summit $^{28}$ - to introduce constitutional rules or framework laws, 'debt brakes', in the member states of the euro area ${ }^{29}$. The fiscal compact agreed at the December 2011 summit specified that under these restrictions members' annual structural deficits should not exceed 0.5 percent of nominal GDP. Before drawing too heavily on the US experience in concluding that constitutional debt brakes are a key solution to Europe's debt problems, however, Europeans should consider three essential aspects of the context in which the balanced budget rules of the states operate. The US experience suggests that the particular path through which rules are adopted and enforced is likely to be critical to their implementation, and that introducing such rules for euro-area member states should be accompanied by a federal system of fiscal powers and a common fund for rescuing and recapitalising banks. We consider these three caveats in turn.

Within the US federal system, the states are 'sovereign' with respect to debt $^{30}$. This sovereignty has two facets. On the one hand, the federal 
government neither mandates nor enforces balanced budget rules for the states. Although states were responding to similar financial problems in similar ways, these rules were adopted autonomously and are implemented independently from the federal government. In modern parlance, states' 'ownership' of these rules is complete. On the other hand, states have no recourse to the federal government when they have difficulty servicing and repaying debt. The federal government assuages funding problems in current expenditures, such as through the ARRA of 2009, but these transfers are largely discretionary and do not relieve state and local governments of debt obligations.

The American constitutional design is thus very different from what European leaders envisage for the euro area: debt brakes that are mandated by the Union and enforced by the European Commission and the EU Court of Justice. The difference is likely to be consequential in two respects. We suspect that local ownership and enforcement make debt brakes more effective than under central mandates, particularly in the context of credible no-bailout norms, and that rules that are centrally mandated are likely to prove to be more brittle than those adopted in a decentralised fashion. When one state violates the rule, as the experience with the Stability and Growth Pact demonstrated, its applicability to other states is less credible. That is less likely to be the case with rules that have been adopted autonomously.

We acknowledge that some of the impetus for debt brakes comes from within euro-area countries. The present crisis could be sufficiently traumatic and thus politically transformative to produce an autonomous reduction in debt tolerance within some of the most afflicted member states, just as the US states adopted balanced budget rules autonomously from the federal government in the nineteenth century. Such an autonomous change in preferences would augur well for the effectiveness of debt brakes. But the strength of the internal shift in debt tolerance is uncertain and is likely to vary significantly among member states.

The second fundamental caveat is that the federal government's 
relationship with the states must be seen within the context of a broader fiscal union ${ }^{31}$. Since Alexander Hamilton's plan was enacted, federal debt has been supported by the full system of federal powers, including a sweeping power to $\operatorname{tax}^{32}$. The federal government's role in public expenditure and taxation is substantial relative to the states. The theory of optimum currency areas has trained attention on the fiscal transfers among different regions of the country that are effected through the federal system of revenue and expenditures as well as through direct budget support to states and local governments. The magnitude of these transfers has been significant, though their exact importance is the subject of some debate.

However, the macroeconomic stabilisation role of the federal government is more important than intra-regional transfers in considering the budget restrictions of the states. Critically, the rigidity brought on by balanced budget provisions at the state level is facilitated by fiscal flexibility at the federal level. Despite the leakiness of these provisions, state and local budgets have behaved procyclically during recessions in the United States. Since the 1930s, the federal budget has helped to stabilise the national economy in countercyclical fashion. Without this, state-level restrictions would have been difficult or impossible to sustain. Although automatic stabilisers might play a greater role in some of the national economies in Europe than in the US states ${ }^{33}$, we believe that creating stringent state-level debt brakes in Europe without a capacity for countercyclical stabilisation would be a serious mistake.

Europe faces a choice between designing debt brakes to provide for countercyclical action at the national level and creating a common countercyclical fiscal instrument of considerably larger size than the present EU budget. Each has advantages and disadvantages. Providing for countercyclical action in national provisions raises problems of enforcement and coordination with the fiscal stance of other members. Which institutions would calculate structural budget positions, ensure that these calculations are unbiased, and provide for consistency across member states? Creating a common capacity for countercyclical action requires strong political cohesion and robust institutions for 
the monetary union. The need for a countercyclical fiscal capacity at one level or the other is not a new observation, but we believe that it is an inescapable one, the implications of which have not yet been sufficiently incorporated in European deliberations about the fiscal architecture.

US banking and capital markets are the third element of the context in which budget rules operate and the states relate to the federal government on fiscal matters. Compared to Europe, banks are less important conduits for finance relative to capital markets and bank regulation is less fragmented, being more of a federal responsibility. Stabilising the banking system, along with stabilising the macroeconomy, has been the responsibility of the federal government. In the US, the states have not themselves undertaken large-scale bailouts or recapitalisation of banks over the last century. As a consequence, the need to stabilise the banking system did not enter into conflict with balanced budget rules at the state level. In the euro area, by contrast, harmonisation of bank regulation is still young, and the fiscal costs of bank rescues and recapitalisation remain primarily a national responsibility. The introduction of debt brakes threatens to collide with the need to mount large-scale rescues of banking systems at the level of member states. As such provisions are put in place, therefore, it is all the more important that the euro area unifies banking regulation and creates a common pool of fiscal resources for rescuing, restructuring and recapitalising banks (Posen and Véron, 2009; Véron, 2011). 


\section{REFERENCES}

Alt, James E. and Robert C. Lowry (1994) 'Divided government, fiscal institutions and budget deficits: evidence from the States', American Political Science Review 88(December): 811-828

Aizenman, Joshua and Gurnain K. Pasricha (2010) 'Net fiscal stimulus during the Great Recession', Working Papers 16779, National Bureau of Economic Research

Amdursky, Robert S. and Clayton P. Gillette (1992) Municipal debt finance law: theory and practice, Aspen Publishers

Ang, A. and F. A. Longstaff (2011) 'Systemic sovereign credit risk: lessons from the US and Europe', Working Paper 16982, National Bureau of Economic Research

Arezki, Rabah, Bertrand Candelon and Amadou N. R. Sy (2011) 'Are there spillover effects from munis?' Working Paper 290 (December), International Monetary Fund

Auerbach, Alan J. (2011) 'Fiscal institutions for a currency union', paper prepared for a conference on Fiscal and Monetary Policy Challenges in the Short and Long Run, sponsored by the Deutsche Bundesbank and the Banque de France, Hamburg, May 19-20

Baunsgaard, Thomas and Steven Symansky (2009) 'Automatic fiscal stabilizers: how can they be enhanced without increasing the size of government?' Staff Position Note SPN/09/23, International Monetary Fund

Bayoumi, Tamim, Morris Goldstein and Geoffrey Woglom (1995) ‘Do credit markets discipline sovereign borrowers? Evidence from the US states', Journal of Money, Credit and Banking vol. 27 (4): 1046-59

Bohn, H. and R. P. Inman (1996) 'Balanced-budget rules and public deficits: evidence from the US states', Carnegie-Rochester Conference Series on Public Policy 45, pp. 13-76

Bordo, Michael D., Agnieszka Markiewicz, and Lars Jonung, 2011. A Fiscal Union for the Euro: Some Lessons from History. NBER Working Papers 17380. Cambridge, MA: National Bureau of Economic Research 
Briffault, Richard (1996) Balancing acts: the reality behind state balanced budget requirements, New York: Twentieth Century Foundation

Chernow, R. (2004) Alexander Hamilton, New York: Penguin Press

Dolls, Matthias, Clemens Fuest and Andreas Peichl (2010) 'Automatic stabilizers and economic crisis: US vs. Europe', Working Paper 16275 , National Bureau of Economic Research

English, W. B. (1996) 'Understanding the costs of sovereign default: American state debts in the 1840s', American Economic Review 86, no. $1: 259-275$

Fatas, A. and I. Mihov (2006) 'The macroeconomic effects of fiscal rules in the US states', Journal of Public Economics 90 (1-2), 101-11?

Follette, Glenn and Byron Lutz (2010) 'Fiscal policy in the United States: automatic stabilizers, discretionary fiscal policy actions, and the economy', Working Paper 43, Finance and Economics Discussion Series, Divisions of Research \& Statistics and Monetary Affairs, Federal Reserve Board

Galligan, Brian (2008) 'Comparative federalism', in R. A. W. Rhodes, Sarah A. Binder and Bert A. Rockman (eds) The Oxford Handbook of Political Institutions, pp. 261-280, 0xford University Press

Gelpern, Anna [2012] 'Bankruptcy, backwards: the problem of quasisovereign debt', Yale Law Journal (forthcoming)

Hallerberg, Mark (2006) 'Fickle fiscal federalism? Fiscal relationships in the US and EU', in Anand Menon and Martin Schain (eds) Comparative federalism, Oxford University Press

Hallerberg, Mark (2011) 'Fiscal federalism reforms in the European Union and the Greek crisis', European Union Politics 12, no. 1: 127-142 Hallerberg, Mark, Rolf Strauch and Jürgen von Hagen (2009) Fiscal governance: evidence from Europe, Cambridge University Press

Hallerberg, Mark and Guntram B. Wolff (2006) 'Fiscal institutions, fiscal policy and sovereign risk premia in EMU', Public Choice vol 136, $3-4$ 
Hamilton, A. (1789) First report on public credit, available at http://press-pubs.uchicago.edu/founders/documents/a1_8_2s5.html Hamilton, A. (1987) Papers of Alexander Hamilton, edited by J. E. Cooke and H. C. Syrett, New York: Columbia University Press

Hines, James R. (2010) 'State fiscal policies and transitory income fluctuations', Brookings Papers on Economic Activity, Fall 2010, pp. 313-33?

Hou, Y. and D. L. Smith (2009) 'Do state balanced budget requirements matter? Testing two explanatory frameworks', Public Choice $145,57-79$

lara, Anna and Guntram B. Wolff [2011] 'Rules and risk in the euro area', Working Paper 2011/10, Bruegel

Inman, Robert, P. (1998) 'Do balanced budget rules work? US experience and possible lessons for the EMU', Working Paper 5838, National Bureau of Economic Research

Inman, Robert P. (2003) 'Transfers and bailouts: enforcing local fiscal discipline with lessons from US Federalism', in J. Rodden, G. Eskelund and J. Litvack (eds) Fiscal decentralization and the challenge of hard budget constraints, MIT Press

Johnson Simon, and James Kwak (2010) Thirteen bankers: The Wall Street takeover and the next financial meltdown, Pantheon Publishing Kasparek, Annika (2011) 'Fiscal policy in US states', Current Issues December 2011, Deutsche Bank Research

Kirkegaard, Jacob Funk (2011) 'What the European Union did and did not accomplish', RealTime Economic Issues Watch, Peterson Institute for International Economics, retrieved on 6 January 2012 from www.piie.com/realtime/?p=2575

Krugman, P. (2008) 'Fifty Herbert Hoovers', New York Times, 29 December

Mahdavi, S. and J. Westerlund (2011) 'Fiscal stringency and fiscal sustainability: Panel evidence from the American state and local gov- 
ernments', Journal of Policy Modeling 33 (6), 953-969

Marzinotto, Benedicta, Andre Sapir and Guntam B. Wolff (2011) 'What kind of fiscal union?' Policy Brief 2011/06, Bruegel

McGrane, C. R. (1935) Foreign bondholders and American state debts, Washington DC: Beard Books

McNamara, Kathleen R. (2002) 'State building, the territorialization of money, and the creation of the American single currency', in David M. Andrews, C. Randall Henning and Louis W. Pauly (eds) Governing the world's money, Cornell University Press

McNichol, E., P. Oliff and N. Johnson (2011) States continue to feel recession's impact, Center on Budget and Policy Priorities, Washington DC

Monkonnen, Eric K. (1995) The local state: public money and American cities, Stanford University Press

National Conference of State Legislatures (2010) 'State balanced budget provisions', NSCL Fiscal Brief, October, available at www.ncsl.org

Oates, Wallace E. (1999) 'An essay on fiscal federalism', Journal of Economic Literature vol. 37 (3), pp. 1120-1149

Orth, John V. (1987) The judicial power of the United States: the eleventh amendment in American history, Oxford University Press

O'Rourke, Kevin (2011) 'A summit to the death', Project Syndicate, 9 December

Perkins, Edwin J. (1994) American public finance and financial services, 1700-1815, Ohio State University Press

Posen, Adam S. and Nicolas Véron [2009] 'A solution for Europe's banking problem', Policy Brief 2009-03, Bruegel

Poterba, James M. (1994) 'State responses to fiscal crises: the effects of budgetary institutions and politics', Journal of Political Economy vol. 102 (4), pages 799-821 
Poterba, James M. (1996) ‘Do budget rules work?' Working Paper 5550, National Bureau of Economic Research

Poterba, J. M. and K. S. Rueben [2001] 'Fiscal news, state budget rules, and tax-exempt bond yields', Journal of Urban Economics 50 , $537-562$

Poterba, J. M. and K. S. Rueben (1999) 'State fiscal institutions and the US municipal bond market', in J. M. Poterba (ed) Fiscal institutions and fiscal performance, University of Chicago Press

Randolph, B. C. (1931) 'Foreign bondholders and the repudiated debts of the Southern states', American Journal of International Law XXV: 74

Ratchford, B. U. (1941) American states debts, Duke University Press

Roberts, A. (2010) 'An ungovernable anarchy": the United States' response to depression and default, 1837-1848', Intereconomics 45 (4), pp. 196-202

Rodden, J. (2006) Hamilton's paradox: the promise and peril of fiscal federalism, Cambridge University Press

Rose, S. (2010) 'Institutions and fiscal sustainability', National Tax Journal 63 (4): 807-838

Savage, J. (1988) Balanced budgets and American politics, Cornell University Press

Sbragia, A. (2008) 'American federalism and intergovernmental relations', in R. A. W. Rhodes, Sarah A. Binder and Bert A. Rockman (eds) The Oxford Handbook of Political Institutions, Oxford University Press.

Sorensen, Bent E., Lisa Wu and Oved Yosha (2001] 'Output fluctuations and fiscal policy: US state and local governments 1978-1994', European Economic Review 45(?): 1271-1310

Sorensen, Bent E. and Oved Yosha (2001] 'Is state fiscal policy asymmetric over the business cycle?' Economic Review, Federal Reserve Bank of Kansas City, issue 0 III: 43-64

Sylla, R. (2011) 'Financial foundations: public credit, the national 
bank, and securities markets', in D. A. Irwin and R. Sylla (eds] Founding choices: American economic policy in the 1790s, University of Chicago Press

Sylla, R. and J. W. Wilson (1999) 'Sinking funds as credible commitments: Two centuries of US national-debt experience', Japan and the World Economy 11, no. 2 (April): 199-222

Véron, N. (2011) 'Testimony on the European debt and financial crisis', Policy Contribution 2011/11, Bruegel

Von Hagen, Jürgen and Charles Wyplosz (2008) 'EMU's decentralized system of fiscal policy', European Economy Economic Papers 306, European Commission, Directorate-General for Economic and Financial Affairs

Wallis, J. J. (2005) 'Constitutions, corporations, and corruption: American states and constitutional change, 1842-1852', Journal of Economic History 65, no. 1:211-256

Wallis, J. J., R. Sylla and A. Grinath (2004) 'Sovereign debt and repudiation: the emerging-market debt crisis in the US states, 1839-1843', Working Paper 10753, National Bureau of Economic Research.

Wallis, John Joseph and Barry R. Weingast (2008) 'Dysfunctional or optimal institutions: state debt limitations, the structure of state and local governments, and the finance of American infrastructure', in Elizabeth Garrett, Elizabeth Graddy, and Howell Jackson (eds) Fiscal challenges: an interdisciplinary approach to budget policy, Cambridge University Press

Wibbels, Eric (2003) 'Bailouts, budget constraints, and leviathans: comparative federalism and lessons from the early United States', Comparative Political Studies 36: 475-508

Woodward, Comer V. (1971) Origins of the New South, 1877-1913, Louisiana State University Press 


\section{NOTES}

1 This essay is adapted from a presentation by Randall Henning at the European Central Bank workshop on Euro-area governance, Frankfurt, 2930 September 2011. The authors wish to thank Jean Pisani-Ferry for his encouragement of this project and Guntram B. Wolff and Nicolas Véron for comments on a previous draft. The final text is the responsibility of the authors alone. This essay is published simultaneously by the Peterson Institute.

2 Ron Chernow (2004) has authored the definitive biography of Hamilton, containing his intellectual development in finance, the implementation of his ideas and his place in the formative period in American history.

3 Sylla [2011] places the development of Hamilton's ideas in the context of the financial challenges at the time. The most commonly cited versions of Hamilton's papers were collected and published by Harold C. Syrett and Jacob E. Cooke in 27 volumes, cited here as 'Hamilton', by volume.

4 Perkins (1994), chapter 9, as cited by Sylla (2011, p19).

5 Sylla (2011) judges Hamilton to be the winner in the overall debate with Gallatin.

6 Recall that Hamilton authored roughly three-fifths of the Federalist Papers and that James Madison, who later split with him over the financial plan, and John Jay were his partners in that ratification campaign.

? Observers who might be dismayed by the present state of US politics, on fiscal matters in particular, can take some measure of consolation from the fact that the American union survived considerably worse divisions over finance in its early years.

8 For a lively contemporary treatment, see Johnson and Kwak (2010, pp1422).

9 Rodden (2006, pp55-64) contains a nice treatment of this period. See, as well, Wallis, Sylla and Grinath (2004), English (1996), and McGrane (1935), a seminal contribution that is rich in historical detail.

10 See, especially, Woodward (1971), pp51-106.

11 Ratchford (1941, p196), quoting B. C. Randolph (1931) 'Foreign bondholders and the repudiated debts of the Southern states', American Journal of International Law XXV, 74. Ratchford's book is one of the classic histories on the debt of the states, covering the colonial period up to the Great Depression.

12 Monkkonen (1995) examines the treatment of local debt and provides a detailed account of the 1870 revision of the Illinois state constitution.

13 A word about nomenclature is in order. In casual usage in the United States, the word 'municipality' usually refers to a city or town. In formal usage in finance, however, 'municipal debt' is a broader category that includes the 
debt of states as well as local entities. 'Local', as distinct from 'state', refers to counties, cities and school and special utility districts.

14 'Bankruptcy rarely offers easy answer for counties' (2011) New York Times, 10 November.

15 Article I, Section 8, gives Congress exclusive legislative jurisdiction over the District of Columbia. The formal name of the control board was the 'District of Columbia Financial Responsibility and Management Assistance Authority'.

16 The Illinois state comptroller is blunt. When speaking about the budget, she says, "It isn't balanced. It's never balanced. There's always ways to have things off budget ..." Financial Times, 4 November 2011.

17 Wallis (2005) notes that these reforms coincide with changes in the law of incorporation and tax rules.

18 The legal literature on state default and fiscal federalism includes Amdursky and Gillette (1992) and Orth (1987). For an up-to-date review, see Gelpern (2012).

19 The meaning of 'golden' as a modifier for 'rule' has shifted in this discourse over time. As we use the term, a golden rule requires that current expenditures and tax receipts be balanced but allows borrowing for long-term public investment. Despite the prevalence of the golden rule at the state level, proposals to differentiate between operating and capital budgets at the federal level have not gained traction in the United States.

20 There is substantial variation among states (Hines, 2010) and, as discussed, the impact of balanced budget rules is contingent on other factors.

21 Oates (1999) argues that macroeconomic stabilisation is best allocated to the central government.

22 Hines (2010) finds that the main source of discretionary spending is the grants-in-aid from the federal government.

23 Standard \& Poor's Municipal Bond Indices at http://www.standardandpoors.com/indices/sp-municipal-bond-maturitybased-indices/en/us/? indexld=spfi--ish-usd----t-------, Securities Industry and Financial Markets Association (SIFMA) and Thomson Reuters. Over the last four years, only California, Connecticut, Illinois and Arizona have financed current expenditure in significant amounts.

24 Kasparek (2011) provides an excellent up-to-date review.

25 Arezki, Candelon and Sy (2011). Exceptions pertain to the largest state issuers.

26 These ratings have not, at least at time of writing, been affected by S\&P'S downgrade of US securities to AA+ in August 2011.

27 Kasparek (2011) argues that risks within the US municipal market have been exaggerated.

28 European Council, 'Statement by the euro-area heads of state or govern- 
ment', Brussels, 9 December 2011, available at http://www.consilium. europa.eu/uedocs/cms_data/docs/pressdata/en/ec/126658.pdf. For brief evaluation of this agreement, see, O'Rourke (2011) and Kirkegaard (2011), among others. For a blueprint for fiscal union, see Marzinotto, Sapir and Wolff (2011).

29 A large number of studies address the effectiveness of fiscal rules in Europe. We will not review that literature here, except to note, by way of example, that lara and Wolff (2011) show that such rules have a significant impact and might have reduced Greece's interest rates by 100 basis points at the outset of that country's crisis. Hallerberg and Wolff (2008) show that the balance of authority between finance ministers and spending ministers within governments has a significant impact on bond yields. See also, von Hagen and Wyplosz (2008) and Hallerberg (2011).

30 Orth (1987) is a classic study of the constitutional law in these respects.

31 For good reviews of the political science literature on fiscal federalism, see Sbragia (2008) and Galligan (2008). For comparisons between the US and the EU, see Hallerberg (2006) and Hallerberg, Strauch and von Hagen (2009). On the relevance of the nineteenth century US for the monetary union, see McNamara (2002).

32 Federal debt is not a joint and several liability of the states per se, as presently discussed with respect to the proposal to issue 'euro bonds', but a common liability of the federal system. The power to tax is critical to the federal government's ability to issue Treasury securities.

33 Dolls, Fuest and Peichl (2010) and Baunsgaard and Symansky (2009). 


\section{ABOUT BRUEGEL}

Bruegel is a European think tank devoted to international economics. It started operations in Brussels in 2005 as a Belgian non-profit international organisation supported by European governments and leading corporations. Bruegel seeks to contribute to the quality of economic policymaking in Europe through open, facts-based and policy-relevant research, analysis and discussion.

Bruegel issues a range of publications. Bruegel Policy Briefs provide concise, topical analysis targeted at an audience of executives and policy decision-makers, with an emphasis on concrete policy orientation. Bruegel Policy Contributions are responses to requests by policymakers or public bodies, including testimonies at hearings or responses to public consultation. Bruegel and its researchers also publish working papers, op-eds, collaborative papers with other organisations, and essays. The Bruegel Essay and Lecture Series provides a compact record of the views of scholars and practitioners as they write for, or lecture at, Bruegel events. Fiscal federalism: US history for architects of Europe's fiscal union is the sixth publication in the Bruegel Essay and Lecture Series.

Bruegel's research is independent and does not represent the views of its board or members. For a full picture of Bruegel activities and publications, visit the website at www.bruegel.org. 


\section{PREVIOUS VOLUMES IN THE BRUEGEL ESSAY AND LECTURE SERIES}

Why Germany fell out of love with Europe, by Wolfgang Proiss I ISBN: 978-9-078910-16-9, July 2010

Politics and trade: lessons from past globalisations, by Kevin O'Rourke ISBN: 978-9-078910-11-4, January 2009

Testing times for global financial governance, by Ignazio Angeloni ISBN: 978-9-078910-08-4, October 2008

10 lessons about budget consolidation, by Jens Henriksson ISBN: 978-9-078910-03-9, July 2007

Will global capitalism fall again? by Jeffry Frieden June 2006

For details of these and other Bruegel publications, visit www.bruegel.org 


\title{
FISCAL FEDERALISM: US HISTORY FOR ARCHITECTS OF EUROPE'S FISCAL UNION
}

\author{
by \\ C. Randall Henning and Martin Kessler
}

European debates on reform of euro-area fiscal governance frequently refer to fiscal federalism in the United States. In light of the 'fiscal compact', agreed by the European Council in 2011, this volume reviews US fiscal federalism from Alexander Hamilton to the present. It is important to note that the US federal government neither mandates balanced budgets nor bails out states in fiscal trouble. States adopted balanced budget rules during the nineteenth century and these rules limit debt accumulation. Before introducing such 'debt brakes' for euro-area member states, however, Europeans should consider that they are likely to be more effective when 'owned' locally rather than mandated centrally, and that maintaining a capacity for countercyclical macroeconomic stabilisation is essential. Finally, because debt brakes threaten to collide with bank rescues, the euro area should unify bank regulation and restructuring.

C. RANDALL HENNING is Professor of International Economic Relations at American University and a Visiting Fellow at the Peterson Institute for International Economics in Washington DC. His work examines economic integration in Asia and Europe, multilateral financial institutions, and macroeconomic and exchange rate conflict and cooperation among $\mathrm{G} 20$ countries.

MARTIN KESSLER is a Research Analyst at the Peterson Institute. He holds a Masters degree from the Paris School of Economics, and previously worked as a research assistant at Bruegel, and an economic analyst at the French embassy in Berlin.

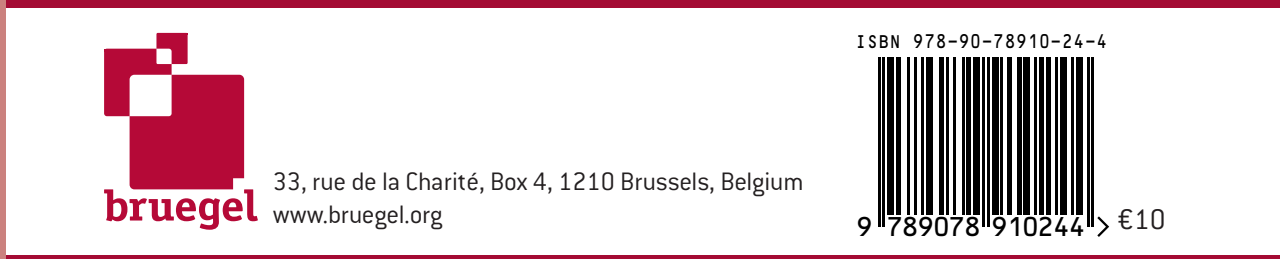

